\title{
Increased mean platelet volume, red blood cell distribution width and platelet / red blood cell distribution width in patients with Hepatitis B
}

\section{Hepatit B'li hastalarda artmış ortalama trombosit hacmi, eritrosit dağılım genișliği ve trombosit / eritrosit dağılım genișliği oranı}

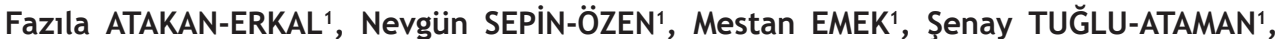 \\ Melek YALÇINKAYA ${ }^{1}$, Nihal AKSOY', Murat ÖZDEMIR ${ }^{2}$
}

\begin{abstract}
Objective: Hepatitis B virus is a major cause of morbidity and mortality worldwide. In chronic hepatitis B patients, routine hematological parameters such as Mean Platelet Volume (MPV), Red Cell Distribution Width (RDW) levels were found significantly higher than healthy persons in recent reports. The present study aimed to investigate the relationship of MPV, RDW and RDW / platelet (PLT) (RPR) in Hepatitis B surface antigen (HBsAg) positive cases.
\end{abstract}

Methods: Patients were evaluated retrospectively between 2011-2012 years in Public Health Laboratory, Antalya. 562 cases of HBsAg positive patients of which were 349 women and 213 men aged between 17-82 years old enrolled the study. During the same period control group were recruited from healthy persons at patient/ control ratio of approximately 3:1 with matching age and sex. Control group was consisted of 121 women and 80 men aged between 18-76 years old. At the same time alanine aminotransferase (ALT), aspartate aminotransferase (AST), PLT, MPV, RDW and RPR levels of patients were investigated.

\section{ÖZET}

Amaç: Hepatit B virüsü tüm dünyada önemli bir morbidite ve mortalite nedenidir. Son yıllardaki çalıșmalarda kronik hepatit B'li hastalarda rutin hematolojik parametrelerden olan ortalama trombosit hacmi (MPV) ve eritrosit dağılım genișliği (RDW) seviyeleri sağlıkı kișilere göre anlamlı olarak yüksek bulunmuștur. Bu çalıșmada Hepatit B yüzey antijeni (HBsAg) pozitif olgularda MPV, RDW ve RDW/Trombosit (PLT) eritrosit dağılım genișliği/trombosit oranı (RPR) ilișkisinin araștırılması amaçlanmıștır.

Yöntem: 2011-2012 yılları arasında Antalya Halk Sağlığ Laboratuvarı'na bașvuran hastalar retrospektif olarak incelemeye alındı. HBsAg pozitif olarak saptanan ve yașları 17-82 arasında değișen 349'u kadın ve 213'ü erkek olmak üzere toplam 562 hasta çalıșmaya alındı. Aynı dönemde yaklașık 3:1 hasta/kontrol oranında sağlıklı kișilerin yaș ve cinsiyet ile eșleșen kontrol grubu olușturuldu. Kontrol grubu, yașları 18-76 arasında değișen 121 kadın ve 80 erkekten olușturuldu. Hastaların eș zamanlı olarak alanin aminotransferaz (ALT), aspartat aminotransferaz (AST), PLT, MPV, RDW ve RPR düzeyleri incelendi.

'Public Health Laboratory, Antalya

${ }^{2}$ Public Health Directorate, Antalya

İletişim / Corresponding Author : Nevgün SEPIN-ÖZEN 
Results: Average age in the HBsAg positive group was found to be $42.07 \pm 12.71$ years. HbsAg negative control group had mean age of $41.21 \pm 13.15$ years. There was no statistically difference of age among patient and control groups $(p=0.367)$. AST and ALT values in HBsAg positive patients were significantly higher than the control group $(\mathrm{p}<0.05)$. PLT, MPV, RDW and RPR levels in patient and control groups were significantly different $(\mathrm{p}<0.05)$.

Conclusion: MPV and RDW levels, were significantly higher in the HBsAg-positive group compared to the control group in our study of which was in accordance with the studies in the literature with Hepatitis $B$ patients. RPR elevation in $\mathrm{HBsAg}$ positive patients is also noteworthy and it's possible relationship to inflammation may lead to new research.

Key Words: HbsAg, MPV, RDW, RPR ratio, Hepatitis B

\section{INTRODUCTION}

Hepatitis B infections remains one of the most common infectious diseases worldwide responsible for considerable morbidity and mortality, and in Asia and Africa in particular (1). Approximately more than 2 billion people in the world have been infected with hepatitis B virus (HBV). Turkey is classified as a country of intermediate endemicity with approximately $4 \%$ of the population being HBV surface antigen (HBsAg) positive $(2,3)$. HBsAg is not only a serological test for HBV infections but also frequently used for screening of HBV positivity in the clinical setting (4). Several previous studies have suggested that there is a link between human coronary artery disease and HBsAg positivity $(5,6)$. In atherosclerosis pathophysiology, the principal processes are platelet activation and aggregation. Previous studies reported that vascular inflammation and atherosclerosis can be explained
Bulgular: HBsAg pozitif grupta yaș ortalaması $42.07 \pm 12.71$ olarak bulundu. HBsAg negatif olan kontrol grubunun yaș ortalaması ise $41.21 \pm 13.15$ olarak saptandı. Yaş gruplarına göre hasta ve kontrol grubunda istatistiksel olarak anlamlı bir fark bulunmadı $(p=0,367)$. AST ve ALT değerleri HBsAg pozitif hastalarda kontrol grubuna göre anlamlı olarak yüksek bulundu $(p<0.05)$. Hasta ve kontrol grubunda PLT, MPV, RDW ve RPR düzeylerinde tüm parametreler açısından anlamlı farklılık saptandı $(\mathrm{p}<0.05)$.

Sonuç: MPV ve RDW düzeyleri, literatürdeki Hepatit B'li hastalarla yapılan çalıșmalarla uyumlu șekilde çalıșmamızdaki HBsAg pozitif hasta grubunda da kontrol grubuna göre anlamlı derecede yüksek saptanmıștır. Ayrıca RPR'nin de HBsAg pozitif hastalarda yüksek olması dikkat çekicidir ve inflamasyonla muhtemel ilișkisi yeni araștırmalara yön verebilir.

Anahtar Kelimeler: HBsAg, MPV, RDW, RPR oranı, Hepatit B with infectious agents (7). The possible mechanism of atherogenesis associated with certain infectious agents has been suggested from the presence of viable microorganisms or their remnants in atherosclerotic plaque with host dependent immunity-related injury $(8,9)$.

Hematological CBC parameters like as mean platelet volume (MPV) and red cell distribution width (RDW) have been evaluated in atherosclerosis to predict disease severity and mortality risk. Platelet activation and function marker MPV; is recently associated with atherothrombosis $(10,11)$. RDW is routinely used to diagnose different types of anemia, but also has been reported as a screening marker for colon cancer and Celiac disease $(12,13)$. In recent years it has been reported that higher RDW rates are associated with high mortality risks 
in patients with cardiovascular diseases $(14,15)$. Elevated MPV and RDW values have been reported to be associated with mortality and other recurrent severe vascular events resulting in cardiac, renal and infectious diseases $(16,17)$. A novel noninvasive index has been developed for determining hepatic fibrosis and cirrhosis in chronic hepatitis B patients. The ratio of RDW/Platelet (RPR) was shown to be a highly accurate marker and application of this index may reduce the need for liver biopsy in patients with chronic hepatitis B patients (18).

In this study we aimed to investigate the association between RDW, MPV and RPR values witth HBsAg positivity.

\section{MATERIAL and METHOD}

\section{Subjects}

In our study we evaluated HBsAg results from computerized patient registry database retrospectively between January 1, 2011 and December 31, 2012 who had admitted Antalya Public Health Care Laboratory which works as a component of Primary Health Care system. $562 \mathrm{HBsAg}$ positive patients 349 women and 213 men aged between 1782 years old (Mean 42.07 \pm 12.71 ) enrolled the study. During the same period control group were recruited from healthy persons at patient/control ratio of approximately 3:1 with matching age and sex. Control group was consisted of 121 women and 80 men aged between 18-76 years old (Mean $41.21 \pm 13.15$ ). According to laboratory results exclusion criterion defined for patients were diabetes mellitus, hypercholesterolemia, dislipidemia, anemia, trombocytopenia or trombositosis. In addition healthy persons who administered their family practitioner as routine control, didn't diagnosed any disease and have normal biochemical and hematologic parameters were chosen as control group. HBsAg, alanine aminotransferase (ALT), aspartat aminotransferase (AST), MPV, PLT, RDW levels were recorded.
Laboratory Assessment

HBsAg was analyzed by chemiluminescence method with Unicel DXI800 (Beckman Coulter, USA) and ALT and AST activities were measured using AU 2700 Analyzer (Beckman Coulter, USA). Platelet, MPV and RDW levels were measured by LH 780 automated hematology analyzer (Beckman Coulter, USA).

\section{Statistical analysis}

For statistical assessment, SPSS 20.0 version was used. Distribution normality was evaluated by Kolmogorov-Smirnov test. Since data were not normally distributed Mann-Whitney $U$ test was performed. The results are given as median ( $\min$-max) and $p<0.05$ considered as statistically significant.

\section{RESULTS}

Demographic data and laboratory findings of patient and control groups are reported in Table 1. Age and sex were similar among groups. There was no statistically difference of age among patient and control groups $(p=0.367)$. AST and ALT values were higher in $\mathrm{HBsAg}$ positive patients than in the control group.(Median $23 \mathrm{IU} / \mathrm{L}$ and $21 \mathrm{IU} / \mathrm{L}$ - Median 20 $\mathrm{IU} / \mathrm{L}$ and $16 \mathrm{IU} / \mathrm{L} \quad \mathrm{p}<0.05$ ). Platelet values (Median $217 \times 103 / \mu \mathrm{L}-252 \times 103 / \mu \mathrm{L}$ ) and MPV values (Median $9.20 \mathrm{fL}-8.70 \mathrm{fL}$ ) were detected respectively among patient group and control group, suggesting a significant difference between two groups $(p<0.05)$.

RDW and RPR ( Median 14.0\%- 0.0641 and Median $13.0 \%-0.0538$ ) were statistically different in patient group than in control group $(\mathrm{p}<0.05)$.

\section{DISCUSSION}

This is the first study, to our knowledge to evaluate MPV, RDW, RPR for hepatitis B seropositive patients. We have found a higher MPV, RDW and RPR levels in the HBsAg positive patients than in the control group. 
Table 1. Demographic and laboratory findings of groups

$\begin{array}{cccc}\text { Parameters } & \text { HbsAg positive group } & \text { Control group } & p \\ \text { Median (Min-Max) } & 562(349 / 213) & \text { Median (Min-Max) } & \text { NS } \\ \text { N (women/men) } & 42.07 \pm 12.71 & 41.21 \pm 13.15 & \text { NS } \\ \text { Age (mean } \pm \text { SD) } & 21(2-293) & 16(5-29) & <0.05 \\ \text { ALT }(\mathrm{U} / \mathrm{L}) & 23(10-209) & 20(12-29) & <0.05 \\ \text { AST }(\mathrm{U} / \mathrm{L}) & 217(102-411) & 252(201-411) & <0.05 \\ \text { PLT }\left(\mathrm{x} 10^{3} / \mu \mathrm{L}\right) & 9.2(7.0-13.0) & 8.7(7.0-11.0) & <0.05 \\ \text { MPV }(\mathrm{fL}) & 14.0(11.0-21.0) & 13.0(12.0-15.0) & <0.05\end{array}$

The link between atherosclerosis, thrombotic process and infection remains the most interesting researches in recent years (9). Based on several reports it seems that MPV, RDW and RPR have diagnostic and prognostic values for different inflammatory conditions (19-21). The relationship between $\mathrm{HBsAg}$ seropositivity and atherosclerosis can be explained by various possible mechanisms. HBV colonization in vascular tissue may cause vascular damage and acute or chronic infection may be associated with vasculitis which may accelerate atherogenesis $(22,23)$. A study in Japanese population reported a positive association between HBsAg positivity and carotid plaque, HBsAg is an independent factor of other risk factors for atherosclerosis identified by highresolution B-mode carotid ultrasound (23). However there were contradiction in some reports. Ghotaslou et al examined patients who underwent coronary angiography and couldn't find an association between hepatitis B infection and coronary atherosclerosis in their study population (24). Sung et al reported that HBsAg seropositivity was associated with a decreased risk of ischemic stroke and $\mathrm{Ml}$ and an increased risk of hemorrhagic stroke. However, they concluded that; these results seemed to be secondary to decreased coagulation status in HBV-associated liver disfunction (25).

Larger platelets demonstrate increased hemostatic capacity in a number of in vitro functional assays. Monitoring of MPV levels in HBsAg positive patients group may provide useful information for assessing the efficacy of antithrombotic treatment for regulating platelet activation. Tarhan et al have found a larger mean platelet volume, a marker of platelet activation, in the chronic hepatitis $B$ patients with inactive disease than controls (1). Ekiz et al reported that MPV was increased significantly in patients with chronic hepatitis B compared with healthy controls which might help in the assessment of fibrosis in chronic hepatitis B (26). In our study MPV was found significantly higher in HBsAg positive patients than control group which confirms these studies.

Increased RDW has been potentially associated with inflammatory conditions such as chronic hepatitis $B$, diabetes mellitus, myocardial infarction, stroke, ulcerative colitis, tuberculosis, acute appendicitis, celiac disease, rheumatoid arthritis in many recent 
reports $(12-16,20,21)$. RDW and platelets were unrelated markers of the liver fibrosis stage in patients with chronic hepatitis B. Yuan Cao et al found that RDW was increased with the worsening of HBV-related liver disease (27). Similar work from Lou et al. was also reported RDW values are significantly increased in patients with hepatitis B and associated with its severity (28). In our study RDW was significantly higher in HBsAg positive patients than control group.

There are limited number of studies about RPR. Baode Chen et al reported that the RDW and the RPR in particular could predict the risk of significant liver fibrosis and cirrhosis (18). In a study conducted by Cetinkaya et al identified RPR as a valuable laboratory test for predicting mortality in acute pancreatitis (21). We found RPR was significantly higher in HBsAg positive patients than control group.

The real mechanisms underlying the increased MPV, RDW, RPR in hepatitis are not clear. MPV, RDW values and RPR in whole blood counts, which is routinely performed for almost all patients admitted to health facilities, may help to solve the problems for trombotic process in HBsAg positive patients.

Finally this study has some limitations. First the study design was sectional and the patients were retrospectively enrolled which cannot establish causality of increased MPV, RDW and RPR in HBsAg positive patients. So this study can only establish an association. Second, this was a single-center study and thus our knowledge about the severity of disease as carrier or chronic/active hepatitis in patients may have posed a limitation in this study.

In conclusion three common hematological parameters which are inexpensive, easily calculated index and no additional cost to the routine complete blood cell counts may serve as an important biomarker for HBsAg positive patients with relatively high accuracy. Further investigations must be provided for the causality of increased MPV, RDW and RPR and their effects in HBsAg positive patients.

\section{REFERENCES}

1. Turhan O, Coban E, Inan D, Nevzat Y.A. Increased mean platelet volume in chronic hepatitis B patients with inactive disease. Med Sci Monit, 2010; 16(4): CR202-5.

2. Ay P, Torunoglu MA, Com S, Cipil Z, Mollahaliloglu $S$ et al. Trends of hepatitis B notification rates in Turkey, 1990 to 2012. Euro Surveill. 2013; 18(47): pii20636.

3. Ocama P, Opio CK, Lee WM: Hepatitis B virus infection: current status. Am J Med, 2005; 118(1413): 15-22.

4. Alizadeh Z, Milani S, Sharifi Z. Occult hepatitis $B$ virus infection among Iranian Blood Donors: A preliminary study. Arach Iran Med, 2014; 17(2): 106-7.

5. Tong DY, Wang $\mathrm{XH}, \mathrm{Xu} \mathrm{CF}$, Yang $\mathrm{YZ}$, Xiong SD. Hepatitis $B$ virus infection and coronary atherosclerosis: Results from a population with relatively high prevalence of hepatitis B virus. World J Gastroenterol, 2005; 11(9): 1292-6.
6. Targher G, Bertolini L, Padovani R, Rodella S, Arcaro G, Day C. Differences and similarities in early atherosclerosis between patients with nonalcoholic steatohepatitis and chronic hepatitis B and C. Journal of Hepatology, 2007; (46): 1126-32.

7. Joseph B. Chronic Infection and coronary atherosclerosis will the hypothesis ever really pan out?. J Am Coll Cardiol, 2011; 58(19): 2007-2009.

8. Epstein SE, Zhou YF, Zhu J. Infection and atherosclerosis: emerging mechanistic paradigms. Circulation, 1999; 100:20-28.

9. Chatzidimitriou D, Kirmizis D, Gavriilaki E, Chatzidimitriou M, Malisiovas N. Atherosclerosis and infection is the jury still not in? Future Microbiol, 2012; 7(10): 1217-30.

10. Murat SN, Duran M, Kalay N, Gunebakmaz O, Akpek $M$, Doger C et al. Relation between mean platelet volume and severity of atherosclerosis in patients with acute coronary syndromes. Angiology, 2013; 64(2): 131-6. 
11. Arevalo-Lorido JC, Caretro-Gomez J, VillarVaca P. Mean platelet volume predicting carotid atherosclerosis in atherothrombotic ischemic stroke. Ir J Med Sci, 2012; 181(2): 179-83.

12. Spell DW, Jones DV Jr, Harper Wf, David Bassman $J$. The value of a complete blood counting in predicting cancer of colon. Cancer Detect Prev, 2004: 28(1): 37-42.

13. Sategna Guidetti C, Scaglione N, Martini S. Red cell distribution width as a marker of coeliac disease: a prospective study. Eur J Gastroenterol Hepatol, 2002 Feb; 14(2): 177-81.

14. Wen Y. High red blood cell distribution width is closely associated wiyh risk of carotid artery atherosclerosis in patients with hypertension. Exp Clin Cardiol, 2010; 15(3): 37-40.

15. Çetin M, Kocaman SA, Bostan M, Canga A, Cicek $\mathrm{Y}$, Erdoğan $\mathrm{T}$, et al. Red blood cell distribution width (RDW) and its association with coronary atherosclerotic burden in patients with stable angina pectoris. Eur J Gen Med, 2012; 9(1): 7-13.

16. Patel KV, Semba RD, Ferrucci L, Newman AB, Fried LP, Wallace RB, et al. Red blood cell distribution width and mortality in older adults: a metaanalysis. J Gerontol A Biol Sci Med Sci Mar, 2010: 65A(3): 258-65.

17. Zampieri FG, Ranzani OT, Sabatoski V, Heraldo PS, Hermes B, Neto LMC et al. An increase in mean platelet volume after admission is associates with higher mortality in critically ill patients. Annals of Intensive Care, 2014; 4: 20.

18. Baode C, Bo Y, Jian Z, Ying L, Chen Y. RDW to platelet ratio: a novel noninvasive index for predicting hepatic fibrosis and cirrhosis in chronic hepatitis B. PloS One, 2013 17; 8(7): e68780.

19. Zareifar S, Farahmand Far MR, Golfeshan F, Caohan $\mathrm{N}$. Changes in platelet count and mean platelet volume during infectious and inflammatory disease and their correlation with ESR and CRP. J Clin Lab Anal, 2014; 28(3): 245-8.
20. Agarwal S, Kumar P, Kapadia S. Association between red cell distribution width (RDW) inflammatory markers and cardiovascular fitness in healthy adults. J Am Coll Cardiol, 2012; 59(13s1): E1179.

21. Cetinkaya E, Senol K, Saylam B, Tez M. Red cell distribution width to platelet ratio: New and promising prognostic marker in acute pancreatitis. World J Gastroenterol, 2014; 20(39): 14450-4.

22. Chatzidimitriou D, Kirmizis D, Gavriilaki E, Chatzidimitriou M, Malisiovas N. Atherosclerosis and infection is the jury still not in? Future Microbiol, 2012; 7(10): 1217-30.

23. Ishizaka N, Ishizaka Y, Takahashi E, Toda E, Hashimato H, Ohno M et al. Increased prevalence of carotid atherosclerosis in hepatit B virus carriers. Circulation, 2002; 105: 1028-30.

24. Ghotaslou R, Aslanabadi N, Ghojazadeh M. Hepatitis $B$ virus infection and the risk of coronary atherosclerosis. Ann Acad Med Singapore, 2008; 37: 913-5.

25. Sung j, Song YM, Choi YH, Ebrahim S, Davey S.G. Hepatitis B seropozitivity and the risk of stroke and myocardial infarction. Stroke, 2007; 38: 1436-41.

26. Ekiz F, Yüksel $O$, Kocak E, Yılmaz B, Altınbaş A, Şentürk ÇS et al. Mean platelet volume as a fibrosis marker in patients with chronic hepatitis B. J Clin Lab Anal, 2011; 25(3): 162-5.

27. Cao Y, Hu Z-D, Hu C-J. An MLP Classifier for Prediction of HBV-Induced Liver Cirrhosis Using Routinely Available Clinical Parameters. Dis Markers, 2013; 35(6): 653-60.

28. Lou YF, Wang MY, Mao WL. Clinical usefulness of measuring red blood cell distribution width in patients with hepatitis B. Plos One May, 2012; 7 (5): e37644. 